\title{
9. CLAY MINERAL STRATIGRAPHY AND DISTRIBUTION IN THE SOUTH ATLANTIC OCEAN
}

\author{
Herman B. Zimmerman, Department of Civil Engineering, Union College, Schenectady, New York
}

\begin{abstract}
Clay mineral stratigraphy from DSDP Leg 39 in the South Atlantic Ocean reflects the effect of paleooceanographic and tectonic events. The early Tertiary occurrence of a montmorillonite-volcanic facies, both in basin and ridge sites, is indicative of extensive volcanism centered on the Rio Grande-Walvis Ridge system. The occurrence of this facies as far north as the Ceara Rise suggests that areas of simultaneous volcanic activity extended into equatorial regions of the Atlantic.

Northward flow of Antarctic Bottom Water cannot be shown to be a major transporting mechanism for sediment from the Antarctic continent to the Argentine Basin. Similarly, the transport of sediment by bottom currents between the basins of the western South Atlantic appears also to be a relatively minor factor in the distribution of clay minerals.
\end{abstract}

\section{INTRODUCTION}

This study is primarily concerned with the variation of the clay mineral assemblage through time in the South Atlantic Ocean. The DSDP is limited to relatively few sites and thus distribution studies are ineffective. Deep drilling, however, provides samples from most of the stratigraphic section and this study, therefore, focuses on the history and variations of clay mineral assemblages and their relationship to paleooceanographic events.

Several syntheses of the distribution of clay minerals throughout the Atlantic Ocean have been published based largely upon piston core data. Yeroshchev-Shak (1961a, b, 1962) and Goldberg and Griffin (1964) described clay mineral distributions within surface sediments in the South Atlantic. A larger study concerned with the entire Atlantic Ocean performed by Biscaye (1965) now forms a baseline for subsequent work on clay mineral distributions in surface and nearsurface sediments. Windom (1969) and Chester et al. (1972) suggested that the central Atlantic Ocean receives a significant portion of its detrital clay material from eolian transport off North Africa whereas Biscaye (1965) and Zimmerman (1975) found that the MidAtlantic Ridge exerts a substantial control over clay mineral distribution throughout the Atlantic and suggested that bottom currents were a major transport mechanism. Because these investigations are limited to surface and near-surface sediments, they describe only the present-day geographic distribution of clay materials. Core materials from the DSDP provides an excellent stratigraphic framework with an adequately high resolution and through a sufficient time span to allow studies on the evolution of clay mineral assemblages in more detail than that obtained from piston coring alone. In combination, sediments sampled by both techniques can be used for investigations of tectonic, paleoclimatic, and paleooceanographic controls on clay mineral occurrences in time and space throughout the South Atlantic Ocean.

\section{METHODS}

An initial set of samples was taken onboard during Leg 39 from each core at every hole (Figure 1), so that all types of sediment facies and characteristic stratigraphic horizons were sampled. In addition, the Leg 39 holes provide a good representation of the two major topographic features of the South Atlantic: the São Paulo Plateau (356), Rio Grande Rise (357), and Walvis Ridge (359) forming a system of major east-west topographic highs, while the Ceara Rise (354), Brazil Basin (355), and Argentine Basin (358) represent deeper water and basinal sites along a north-south traverse west of the Mid-Atlantic Ridge. Six piston cores, with bases dated as Pleistocene, were also sampled at the Lamont-Doherty Core Laboratory (Figure 1, Table 1). These were selected along a north-south traverse of the western South Atlantic to provide control on presentday sediment variations across modern climatic zones and along the path of flow of the Antarctic Bottom Water.

Detailed descriptions of sample preparation for X-ray diffraction analysis are given in Biscaye (1965), Jackson (1969), and Zimmerman (1972). Calcium carbonate was removed by treatment with $0.6 \mathrm{~N}$ acetic acid solution followed by decantation and settling in accordance with calculated times for separation of the $<4 \mu \mathrm{m}$ fraction. Preferred orientation slides were then prepared of this clay-sized material. A size fractionation results from 


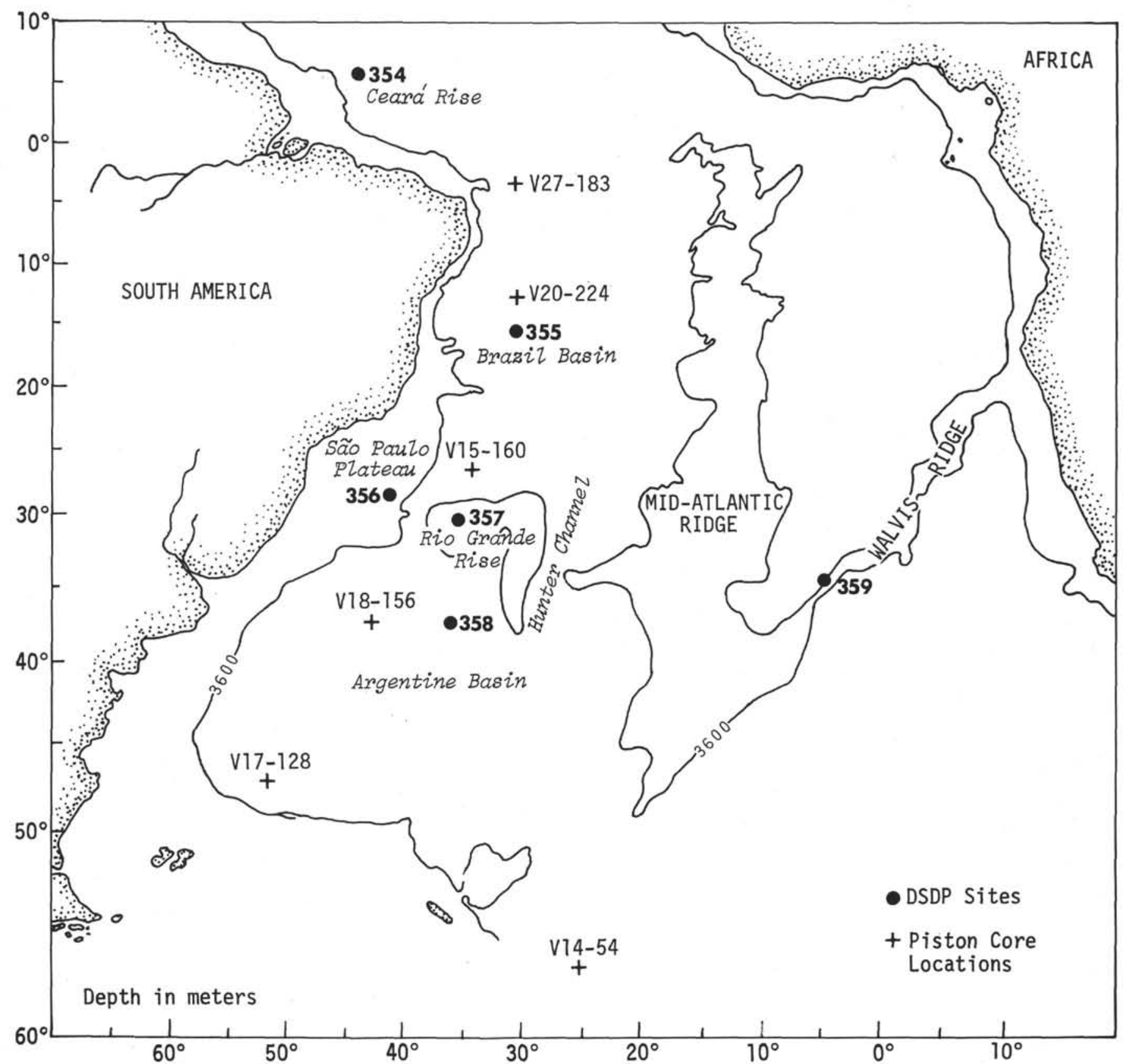

Figure 1. Index chart of South Atlantic Ocean, showing locations of drill sites and piston cores.

this method enhancing the relative amounts of clay minerals comprising the smaller particle sizes such as montmorillonite (Gibbs, 1968). As will be noted from the results, however, the variation in abundance of montmorillonite and most other components are very large, thus minimizing the effects of this error. In order to test for X-ray diffraction interference by amorphous silica and aluminum, selected samples rich in diatoms and Radiolaria were treated with the hot $0.5 \mathrm{~N} \mathrm{NaOH}$ procedure of Hashimoto and Jackson (1960).

Each slide was analyzed by X-ray diffraction through a scan of $3^{\circ}$ and $14^{\circ} 2 \theta$ both before and after being subjected to an ethylene glycol atmosphere for at least 24 hr. Selected samples were scanned through wider ranges as a check on mineral identifications utilizing additional orders of diffraction peaks. A General Elec-

TABLE 1

Location Data for Piston Cores

\begin{tabular}{crrc}
\hline Core & Latitude & Longitude & $\begin{array}{c}\text { Depth } \\
(\mathrm{m})\end{array}$ \\
\hline V27-183 & $3^{\circ} 33^{\prime} \mathrm{S}$ & $30^{\circ} 32^{\prime} \mathrm{W}$ & 4694 \\
V20-224 & $13^{\circ} 00^{\prime} \mathrm{S}$ & $30^{\circ} 10^{\prime} \mathrm{W}$ & 5405 \\
V15-160 & $26^{\circ} 21^{\prime} \mathrm{S}$ & $34^{\circ} 36^{\prime} \mathrm{W}$ & 5044 \\
V18-156 & $37^{\circ} 27^{\prime} \mathrm{S}$ & $42^{\circ} 50^{\prime} \mathrm{W}$ & 6046 \\
V17-128 & $47^{\circ} 06^{\prime} \mathrm{S}$ & $51^{\circ} 46^{\prime} \mathrm{W}$ & 4468 \\
V14-54 & $56^{\circ} 51^{\prime} \mathrm{S}$ & $25^{\circ} 08^{\prime} \mathrm{W}$ & 6181 \\
\hline
\end{tabular}


tric XRD-7 diffractometer was used with nickelfiltered, $\mathrm{Cu} \mathrm{K}_{\alpha}$ radiation at a $2^{\circ} 2 \theta /$ min scanning speed with a slow scanning rate in the $24^{\circ}$ to $26^{\circ} 2 \theta$ range. Basal reflections were used for identification of the major clay mineral phases. The area under the $7.1 \AA$ peak was used as an indication of the abundance of chlorite and kaolinite, with the slow-scan method of Biscaye (1964) applied as a means of identifying and separating these two minerals.

Semiquantitative estimates of the crystalline components were determined by concentration factors described by Biscaye (1965), Rex (1969), and Zemmels and Cook (1973). Proportions of montmorillonite, kaolinite, illite, and chlorite were normalized to $100 \%$, even where fine-grained clinoptilolite/heulandite was present (McCoy, Zimmerman, and Krinsley, this volume). These methods give results that are internally consistent, and therefore, allow an interpretation of the relative changes in clay mineral content occurring over long time spans.

\section{RESULTS}

\section{Piston Core Sediments}

The piston core samples (Table 1) consist of Recent and Pleistocene sediments along a north-south traverse in the western South Atlantic and are used to establish a modern base for clay mineral stratigraphy. Variations in clay abundances are relatively minor throughout the core length (Figure 2), the largest being in core V18-156 where a particularly pronounced increase in montmorillonite is seen at 3 meters.

Generally, the most conspicuous changes occur between the cores indicating a geographic influence in the clay mineral suite. This is well illustrated by typical $\mathrm{X}$-ray diffraction patterns (glycolated) along the northsouth traverse (Figure 3 ) where distinct changes in both assemblage and crystallinity occur. Illite is present in all cores, but in the equatorial regions its presence is diluted by kaolinite and montmorillonite. In higher latitudes illite is dominant, but the crystallinity and abundance of the entire clay suite decreases to a great extent compared with that in equatorial regions.

Kaolinite-chlorite relationships follow that described by Biscaye (1965) and Goldberg and Griffin (1964). Kaolinite is abundant at low latitudes and diminishes towards higher latitudes in the south, whereas chlorite appears to be more prevalent in the higher latitudes and becomes relatively less important in equatorial regions.

The Rio Grande Rise forms the boundary between a province of high montmorillonite abundance to the north and an area of relatively lower concentration in the Argentine Basin to the south. The most northerly core in the Argentine Basin (V18-156) exhibits a variable but generally low montmorillonite abundance, with the two more southerly cores having uniformly small amounts of montmorillonite.

\section{Drill Sites in Basins}

Widely differing lithologies characterize the three basin sites. The Ceara Rise consists predominantly of carbonate deposition with a zeolite and biosiliceous unit in the Oligocene. The Brazil Basin is dominated by terrigineous silts and mud with a conspicuous zeolite component; the Cretaceous section consists of limestone. Biosiliceous muds dominate the upper section in the Argentine Basin to the mid-Eocene where a carbonate-mud becomes prevalent during Cretaceous in the lower portion of the hole.

\section{Ceará Rise (354)}

On the Ceara Rise, clay minerals form three distinct clay facies (Figure 4). In the late Cretaceous basal sediments, kaolinite dominates the clay mineral suite with some illite; montmorillonite is absent. The unconformity at the Cretaceous-Tertiary boundary marks an abrupt change in this clay mineral assemblage. In the lower Tertiary clay facies, above the unconformity, montmorillonite is dominant, constituting the entire clay fraction during the Paleocene. Montmorillonite content slowly decreases upwards through the Tertiary section, with a concomitant rise in the kaolinite content while illite is present in significantly lower concentrations.

The Eocene-Oligocene hiatus, noted in the lithology section of the Ceara Rise, is not marked by a change in the clay mineral assemblages. The lower Tertiary sequence forms four separate lithologic units through which there is a generally decreasing clay content. Zeolite is common in the Oligocene-early Miocene section and the entire lower Tertiary facies may generally be described as being similar to the "oceanic" facies of Heath (1969).

From the mid-Miocene hiatus to the present, the sediments of the upper Tertiary clay facies are characterized by an assemblage that is dominated by illite with smaller amounts of montmorillonite. Chlorite occurs as a minor constituent. Kaolinite abundances are greater than those seen at other sites, but are not as high as kaolinite concentrations within the basal clay facies. Generally, the amount of kaolinite within the upper Tertiary sequence is similar to abundances found in piston cores, and the facies may be described as being similar to Heath's "continental" sediment.

\section{Brazil Basin (355)}

The late Cretaceous-Paleocene unconformity in the Brazil Basin also marks a major break in clay mineral assemblages. Below the unconformity, the basal assemblage is predominantly illitic clays with minor montmorillonite and kaolinite, in contrast to the predominantly kaolinite assemblage in the basal Cretaceous sediments of the Ceara Rise. The unconformity in the Brazil Basin, however, distinctly marks a similarly abrupt increase of montmorillonite in the lower Tertiary sediments.

The mid-Miocene to Paleocene sediment (lower Tertiary clay facies, Figure 4 ) is characterized by a highly variable clay mineral assemblage that may be considered as two alternating subfacies. One consists of an illitic suite whereas the other is dominated by montmorillonite. Both contain relatively minor amounts of kaolinite with only a trace of chlorite.

A characteristic upper facies, correlatable with the upper Tertiary facies of the Ceara Rise, is difficult to define here. At the Ceara Rise, the mid-Miocene hiatus 


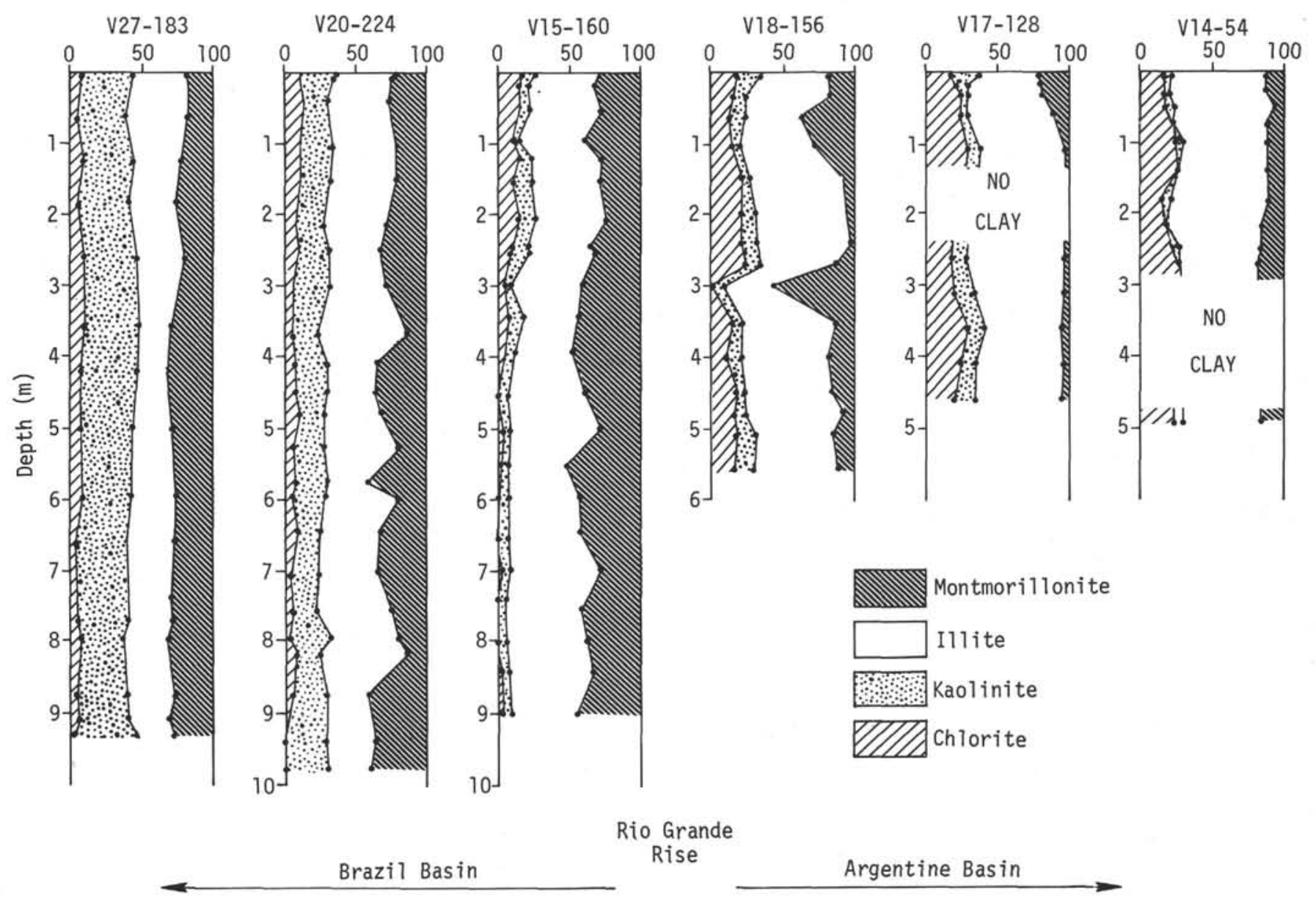

Figure 2. Abundance of clay minerals in piston cores arranged in a north-south traverse, western South Atlantic.

clearly marks an increase in illite content as well as a small but notable increase in chlorite content. A similar sequence may be present in the Brazil Basin; however, the wide spacing of cores in this part of the section does not allow a clear resolution of a correlative "continental" facies. The piston core in this area (V20-224) also shows a clay dominated by illite suggesting that an upper "continental" facies may be present.

\section{Argentine Basin (358)}

In the Argentine Basin the clay mineral stratigraphy is not as clearly separable into facies. The basal clay facies is characterized by abundant illite and some kaolinite, similar to the basal facies of the Brazil Basin. The facies differs, however, in that montmorillonite forms a significant portion of the assemblage, whereas it constitutes only a minor proportion of the late Cretaceous clays in the more northerly sites. A change in clay assemblage at the Cretaceous-Paleocene boundary occurs where an unconformity is suggested. However, the abrupt increase in montmorillonite noted at Sites 354 and 355 does not occur here, but rather forms a gradual increase during Paleocene and reaches a maximum in the mid-Eocene. From mid-Eocene, the montmorillonite content decreases continuously to a low during the Miocene, while illite varies inversely reaching a maximum in the early Miocene. The top three cores at this site again show an important montmorillonite component. Chlorite and kaolinite are present throughout the Tertiary section as minor constituents. The absence of sharp changes in assemblage make it difficult to assign clay facies designations to the post-Eocene section of the Argentine Basin.

The three basin sites show a marked change in clay mineral contents in the Miocene, although in the Ceará Rise and Argentine Basin this change is apparently in the opposite sense. Thus, the Miocene of the Ceará Rise shows an increase in illite, wherease in the Miocene of the Argentine Basin the illite component decreases. Any change, however, is poorly resolved in the Argentine and Brazil basins due to the wide spacing of cores.

\section{Drill Sites on Ridges}

\section{São Paulo Plateau (356)}

Ridge sites show completely different clay mineral characteristics (Figure 5). Sediments cored at Site 356 on the São Paulo Plateau are typified by variable quantities of illite and montmorillonite with minor amounts of kaolinite and no chlorite. The montmorillonite-illite relationship varies reciprocally without any long-term trend, except montmorillonite is somewhat more prevalent in the Paleocene and lower Eocene sections. The variable montmorillonite-illite facies is similar to 


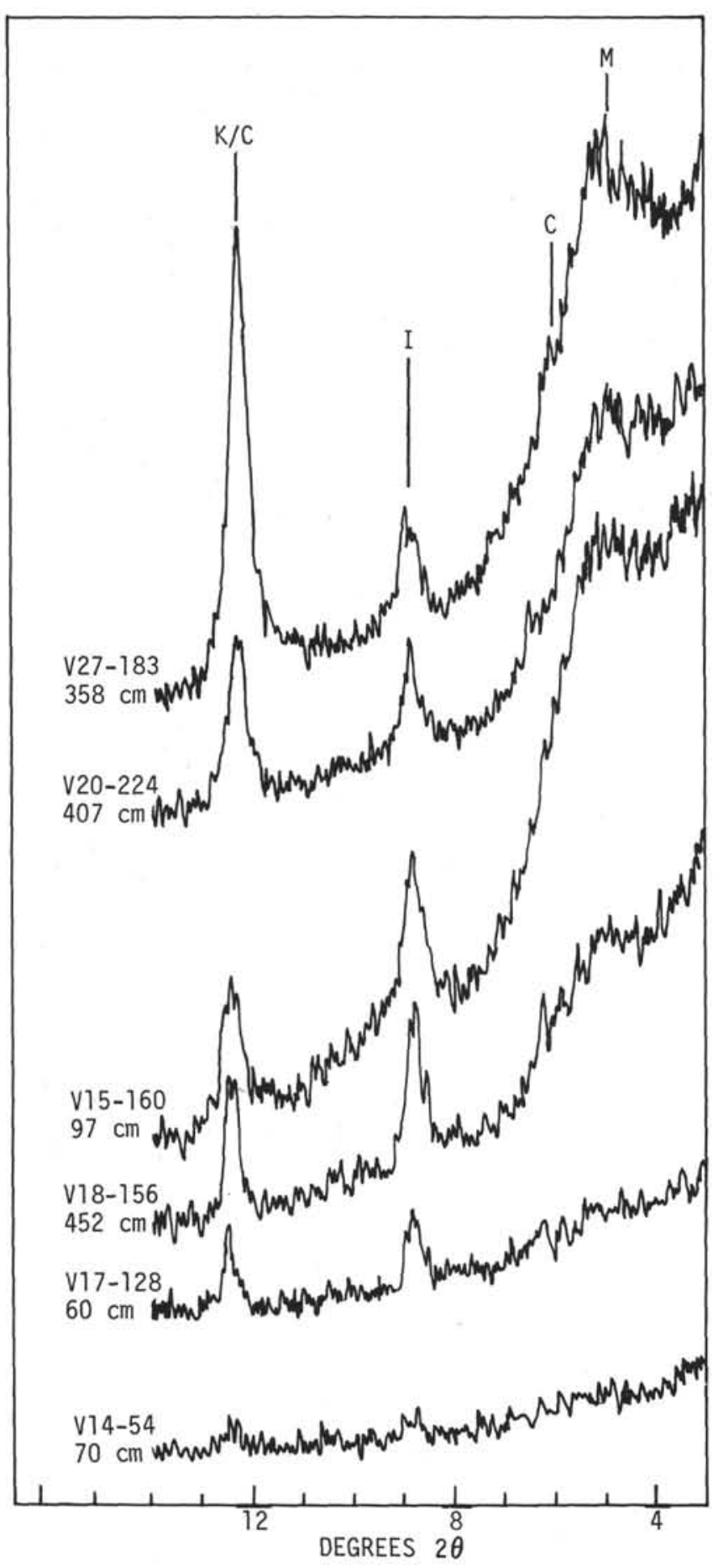

Figure 3. Typical X-ray diffractograms (glycolated) of piston core clay mineral assemblage, illustrating North-south variation in composition and crystallinity; (all patterns recorded at the same scale factor, $1 \mathrm{k} \mathrm{cps).} \mathrm{Treatment} \mathrm{by}$ the method of Hashimoto and Jackson (1960) to remove interference of amorphous silica enhances the diffraction pattern of the two southern cores (V14-54, V17-128) to some extent but does not appreciably alter the trends (this procedure also tends to dissolve some of the montmorillonite phases).

the lower Tertiary clay facies of the Brazil Basin, but at the São Paulo Plateau these assemblages extend into the Cretaceous with the basal clay of Albian age, consisting of $100 \%$ montmorillonite.

Rio Grand Rise (357) and Walvis Ridge (359)

Clay mineral stratigraphy of the Rio Grande Rise (Site 357) exhibits two prominent assemblages. The first is dominated by illite with minor amounts of kaolinite, chlorite, and montmorillonite. This facies occurs throughout the sediment column here and alternates in post-Eocene sediments with intervals containing no clay minerals.

The second facies is dominated by montmorillonite. It is prominent in the Santonian section, but is best developed in the Eocene in association with finegrained clinoptilolite and with a mid-Eocene volcanic flow. This facies is also apparent at Site 359, the Walvis Ridge, where it is the only clay mineral suite present. Here too, the montmorillonite is closely associated with an Eocene volcanic flow while the upper portion of the sediment column contains no clay minerals.

\section{DISCUSSION}

The work of Biscaye (1965), Griffin et al. (1968), and Rateev et al. (1969) has shown that the distribution of clay minerals in recent marine sediment is chiefly detrital and related to general source areas on adjacent continents. Diagenetic alteration does not provide a viable alternative explanation for the observed stratigraphy. The very abrupt changes in composition, the general absence of long-term trends, and the association of some facies changes with unconformities suggest that postdepositional alteration within the "terrestrial" clay mineral suite is relatively minor. Occurrence of clays composed entirely of montmorillonite, however, is best explained as an in situ alteration of volcanic materials where no large continental source is evident (as in the northern Indian Ocean, Goldberg and Griffin, 1970). The association of montmorillonite with basaltic volcanism is clear (Peterson and Griffin, 1964) and further, its association with zeolite minerals point to a significant degree of diagenetic activity.

\section{Influence of Climate}

Piston cores (Figure 2) show no systematic change in clay mineral assemblage with depth. However, they do illustrate (Figure 3 ) the change in assemblage that occurs on a longitudinal traverse from tropical to high latitude terrestrial weathering regimes. The prevalence of kaolinite in soils formed under tropical conditions and the strong association of kaolinite in deep-sea sediments with tropical land masses is well known (e.g., Biscaye, 1965; Goldberg and Griffin, 1964). The piston cores also illustrate the reciprocal relationship of kaolinite with chlorite, the latter concentrated in the higher latitudes where mechanical weathering is most intense.

The behavior of illite crystallinity is in contradiction to Chamley's $(1967,1972)$ hypothesis, in which warm moist conditions in the equatorial regions produce poorly crystallized illite through chemical weathering, whereas well-crystallized illite is produced in higher latitudes by mechanical weathering. Jacobs (1974) found well-crystallized illite in Antarctic sediments of 

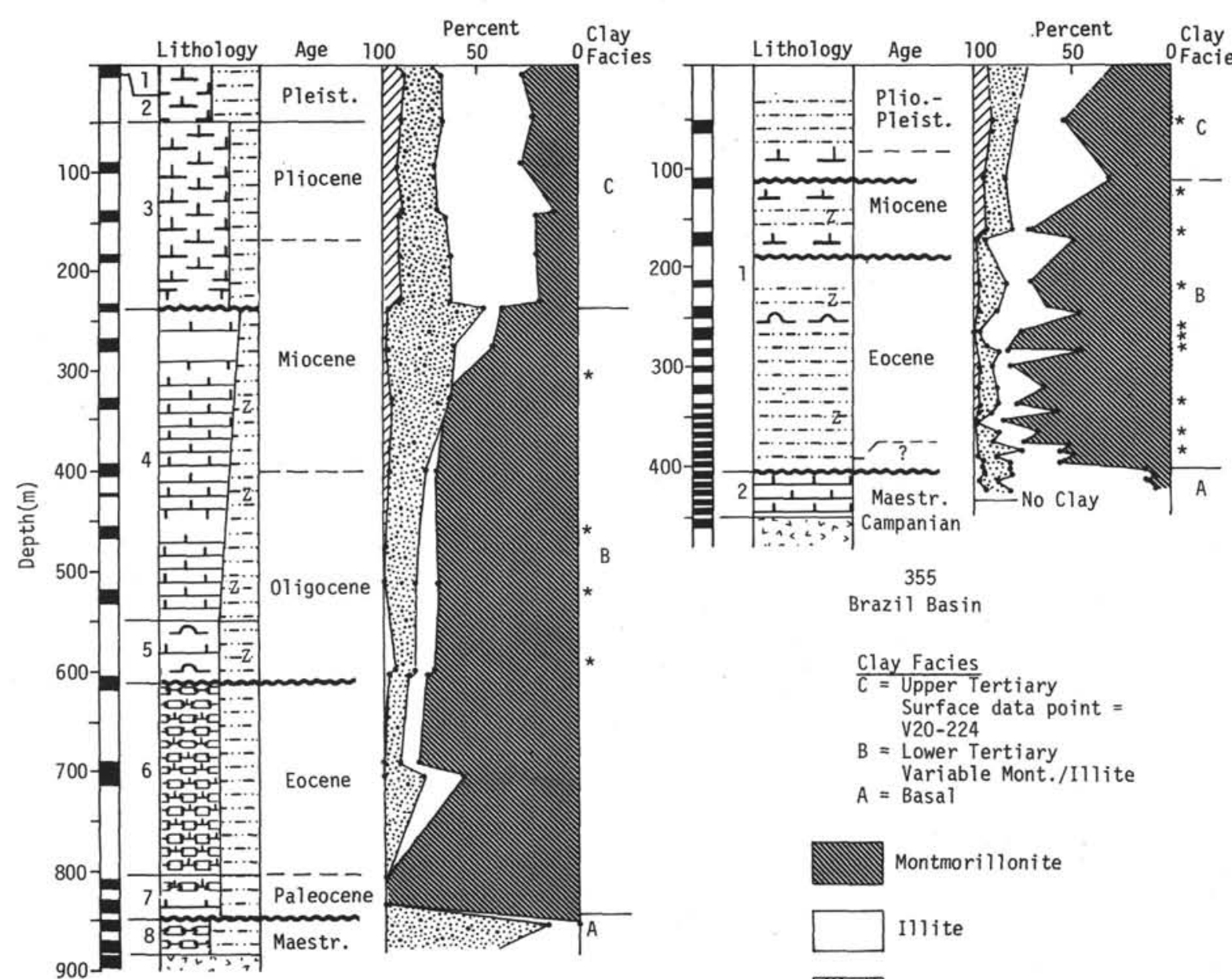

$$
\begin{aligned}
& 355 \\
& \text { Brazil Basin } \\
& \text { Clay Facies } \\
& \text { V20-224 } \\
& A=\text { Basa }] \\
& \square \text { Illite } \\
& \text { Kaolinite } \\
& \text { Dla chlorite } \\
& \text { * Zeolite }
\end{aligned}
$$$$
\text { = Upper Tertiary }
$$$$
\text { Surface data point }=
$$$$
B=\text { Lower Tertiary }
$$$$
\text { A Variable Mont./Illite }
$$$$
\text { Montmorillonite }
$$

Clay Facies

$C=$ Upper Tertiary
$B=$ Lower Tertiary

$B=$ Lower
$A=$ Basal

Figure 4. Abundance of clay minerals in basin drill sites Leg 39, western South Atlantic Ocean.
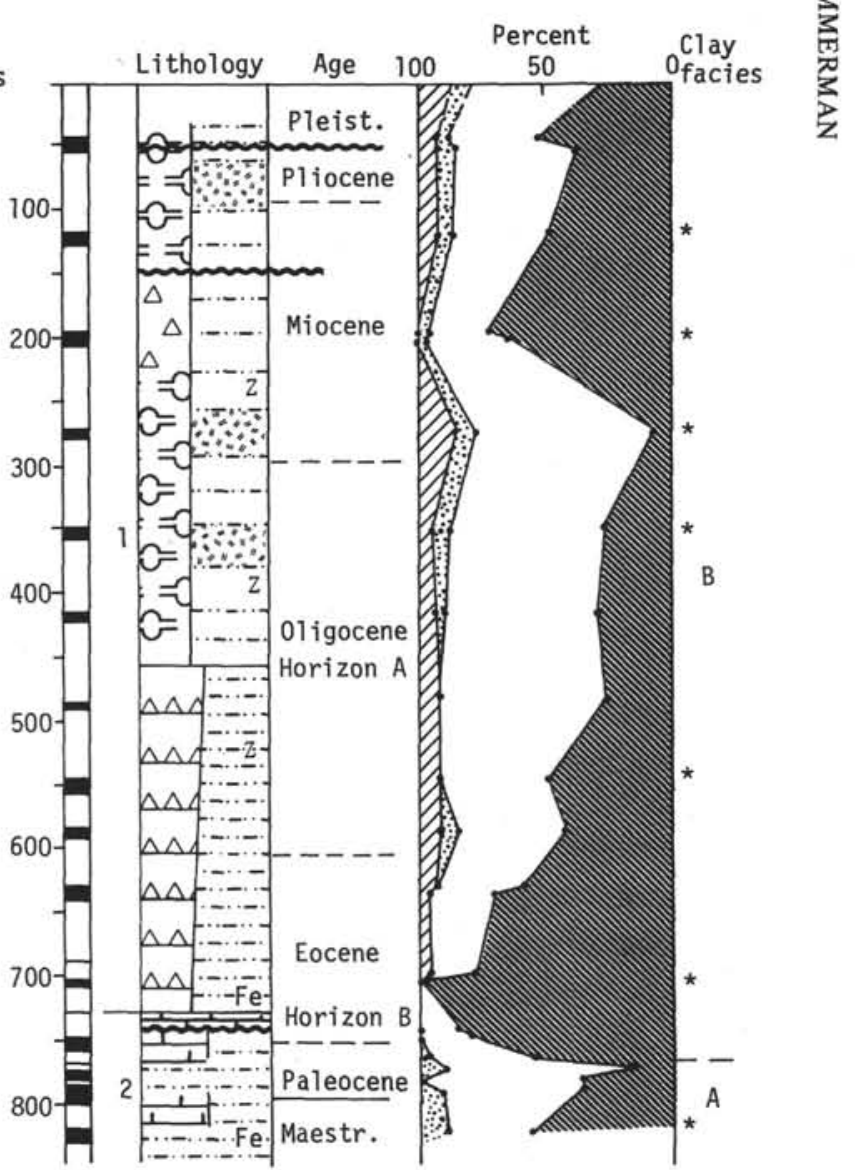

358

Argentine Basin

\section{Clay Facies}

= Variable Mont./I1lite Surface data point $=$ $A=$ Basal 


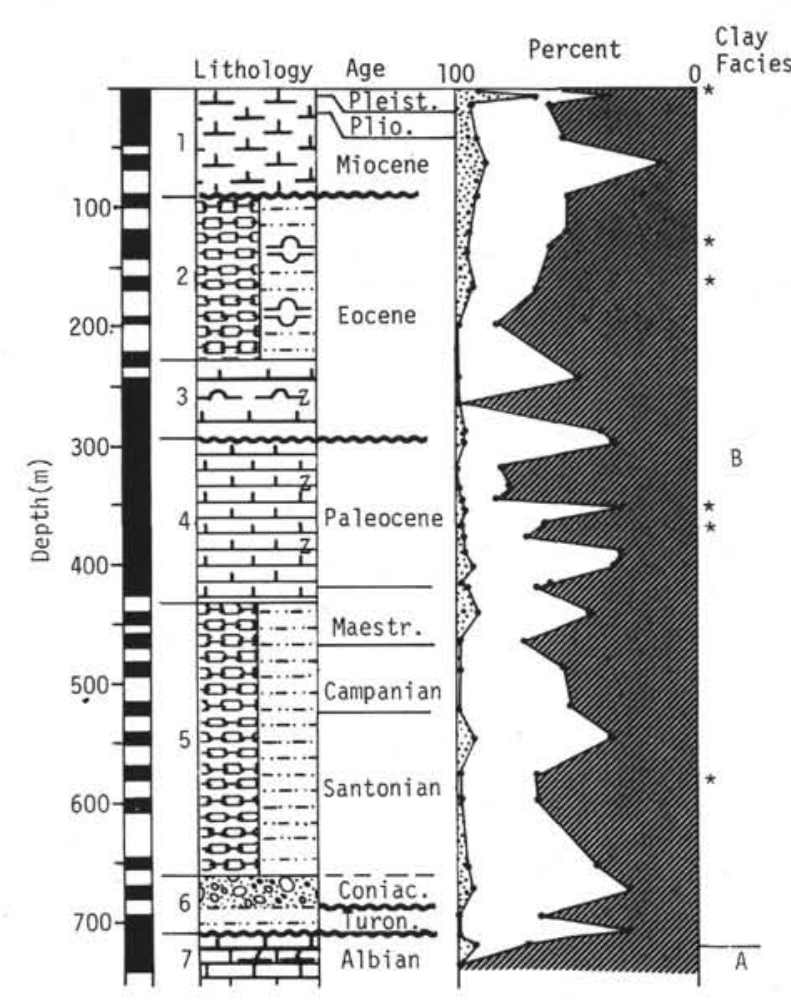

356

Sao Paulo Plateau

$$
\begin{aligned}
& \frac{\text { Clay Facies }}{A=\text { Montmorillonite }} \\
& B=\text { Variable } \\
& \text { Mont./Illite }
\end{aligned}
$$
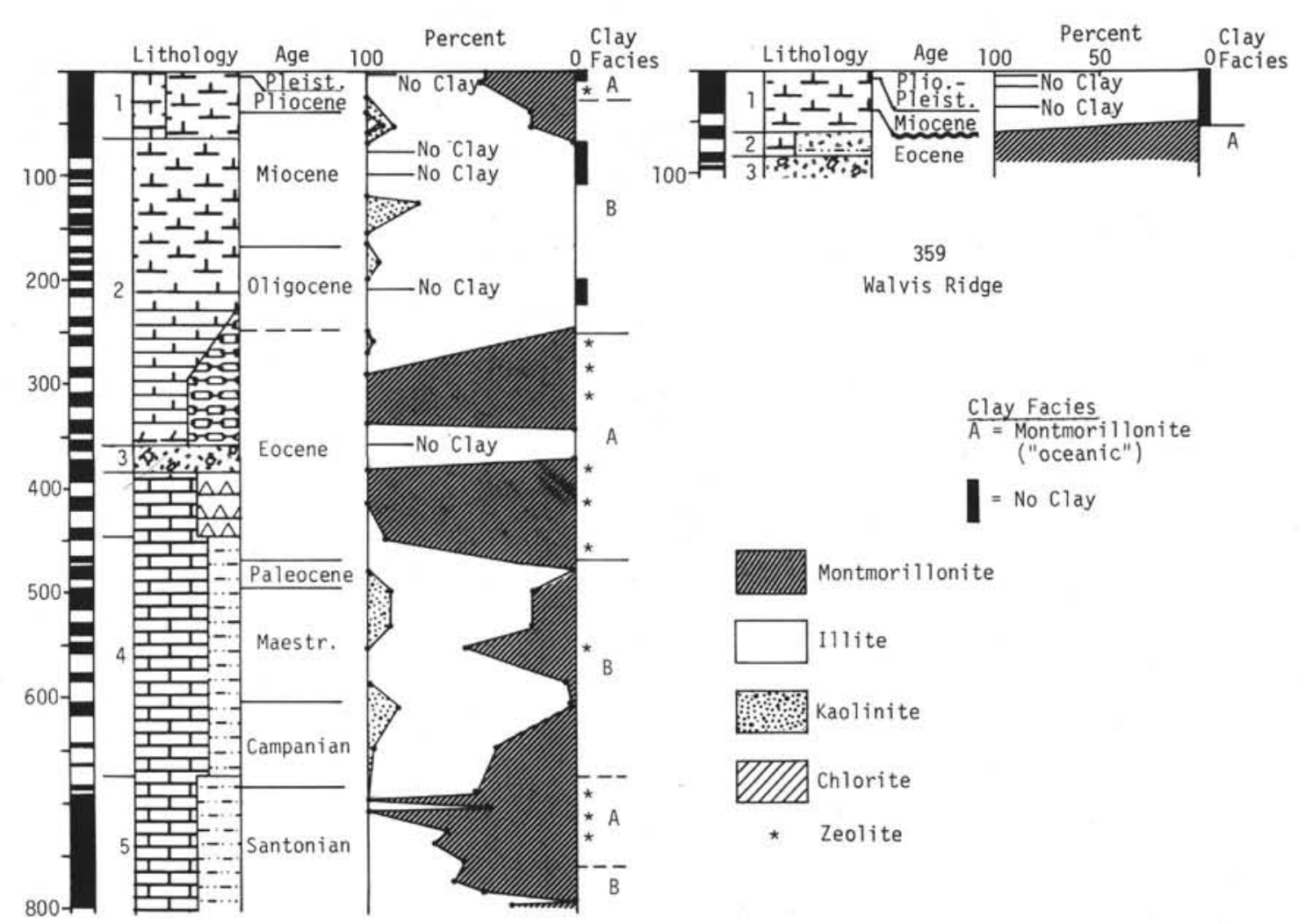

357

Rio Grande Rise

$$
\begin{aligned}
& \frac{\text { Clay Facies }}{A=\text { Montmorillonite }} \\
& \text { ("oceanic") } \\
& \text { Illite } \\
& \text { = No Clay }
\end{aligned}
$$

$\frac{\text { Clay Facies }}{\text { A = Montmorillonite }}$ ("oceanic")

$\boldsymbol{D}=$ No Clay

Montmorillonite $\square$ I1lite

Kaolinite

DIIChiorite

* Zeolite

Figure 5. Abundance of clay minerals in ridge drill sites Leg 39, South Atlantic Ocean. 
Plio-Pleistocene age, supporting Chamley's observations; and Jacobs and Hays (1972) used this relationship in the equatorial Pacific to support their contention of increased continental erosion in the late Cenozoic. The trend towards poor crystallinity with high latitude observed in our longitudinal traverse may be a result of the great distance between the most southerly core (V14-54) and the Antarctic continent, the presumed source of the illitic sediments in the southernmost cores. Northward transport of clay minerals in this region is most probably accomplished by Antarcic Bottom Water (AABW) which may be transporting only the finest illite grains (with resulting poor crystallinity) by the time it enters the Argentine Basin. Since no large input of clays would be expected between Antarctica and the southwestern Argentine Basin, the abundance of all the clays appears correspondingly small.

This suggestion, that only small amounts of clay are introduced by $\mathrm{AABW}$ into the southern Argentine Basin, is supported by examination of the region's suspended sediment turbidity (Eittreim et al., in preparation). The AABW greatly increases its turbidity after entry into the basin, indicative of significant local sources of suspended material, presumably through bottom erosion or detrital injection from the basin's western rim. A similar system appears to be operative in the Cape Basin, where the highest turbidity also is not associated with the entrance of AABW into the basin (Eittreim et. al., in preparation) implying that suspended material is acquired along its subsequent path of circulation. Illite is also not associated with AABW flow in the south western Indian Ocean (Goldberg and Griffin, 1970; Kolla and Biscaye, 1975). The long-distance transport of well-crystallized Antarctic illite (as well as other suspended material) is not, therefore, a significant factor for deposition in downstream areas of the AABW. In the western basins of the South Atlantic, later additions from the South American continent, along the northward route of the $\mathrm{AABW}$, again increase the clay mineral abundance.

Examination of the stratigraphic column of any site reveals little in the way of clay mineral trends based upon the Cenozoic deterioration of the climate. In the Rio Grande-Walvis Ridge sites, the clay minerals are dominated by a volcanogenic assemblage. Kaolinite content of the Ceará Rise appears to increase somewhat from Eocene through Miocene, but is then interrupted by the sudden increase in illite and chlorite, most probably connected with the initiation of the Amazon drainage system. Sediment from the Argentine Basin shows a long-term trend of increasing illite (and chlorite) content which may be induced by the climatic deterioration, but it too is interrupted by a Miocene increase in montmorillonite content. The clay minerals of the São Paulo Plateau and the Brazil Basin are similar with a fluctuating montmorillonite and illite facies, but here too it is difficult to discern any climatic-induced trends from the rapidly alternating facies. We may conclude that any climatic influence present in the composition of the clay mineral suite is easily overcome by extraclimatic events.

\section{Stratigraphy of the São Paulo-Rio Grande- Walvis Ridge System}

The oldest clay minerals recovered are of Albian age from the São Paulo Plateau (Figure 5) and consist of $100 \%$ montmorillonite. It is difficult to speculate on the significance of one sample, but given the small size of the South Atlantic basin at this time and its actively spreading mode, one might expect the production of widespread volcanogenic deposits with later devitrification to montmorillonite. A continental origin, however, cannot be ruled out. The absence of zeolite and volcanic shards, the close proximity of the continent, and the disturbed nature of the sediment (Site Report Chapter 356) suggest that a terrestrial source is also feasible. The rest of the column at the São Paulo Plateau alternates between a montmorillonite (often associated with zeolite and volcanic glass) and an illitic facies suggesting, respectively, oceanic-volcanic and terrestrial influence. Da Rocha et al. (1975), however, report a similar montmorillonite and illite assemblage on the continental shelf adjacent to the São Paulo Plateau. To some extent, therefore, terrestrial input is feasible throughout the column and may act as an important control on the composition of the clay minerals.

The basal sediments from the Rio Grande Rise are illitic, but become enriched in the montmorillonitezeolite-volcanic glass facies in late Santonian time possibly reflecting an initial active stage in Rio Grande Rise volcanism. In the late Cretaceous, the absence of montmorillonite and the resumption of predominantly illitic deposition suggests the cessation of volcanic input and renewed terrestrial influence. The saddle of the Vema Channel does not allow direct bottom transport of fine sediments to this location, therefore, atmospheric and mid-water processes are the most likely transport modes for the illite facies. In early Tertiary, active volcanism on the Rio Grande Rise again provided an influx of volcanic material. During this time volcanism was also prevalent on the Walvis Ridge (Site Report Chapter 359), while the São Paulo Plateau exhibits an enrichment of montmorillonite.

On the Rio Grande Rise the montmorillonite clays are associated with clinoptilolite and on both the Rio Grande and Walvis ridges the assemblage is in close association with volcanic material. Thus, the clay mineral suite of the entire east-west ridge system is correlatable in the Eocene and provides evidence for active and extensive volcanism at this time for the South Atlantic Ocean.

The remainder of Tertiary sediments on the Rio Grande Rise are predominantly illitic alternating with calcareous sediments in which clays are absent. PostEocene sediment of the Walvis Ridge shows the complete absence of crystallized clay minerals in a pelagic carbonate sequence. The intermittent absence of clays on the Rio Grande Rise and their total absence on the Walvis Ridge is not an erosional effect since the pelagic sequences are more or less continuous throughout the column; rather, it is indicative of the transporting mechanism on topographically positive features. Since 
deep bottom currents are ineffective on a ridge, the dominant detrital input is apparently restricted to atmospheric-pelagic mechanisms. Both sites are in the zone of the Westerlies; the Rio Grande Rise, however, is in relatively closer proximity to the South American continent, allowing deposition of wind-borne detritus on a more or less continuous basis. The Walvis Ridge, on the other hand, is far downwind of the South American continent and has no immediate source for atmospheric input; accordingly deposition of terrestrially derived clay minerals does not occur in significant amounts.

\section{Eocene Volcanism}

The Cretaceous-Tertiary unconformity (Sites 354, 355 , and 358) with an extreme change in clay mineral assemblage is suggestive of a major geologic event influencing the entire South Atlantic Ocean. The preTertiary sediments of the basinal sites consist of clay facies that are quite different from one another (Figure 4). In all three sites, however, the onset of Tertiary sedimentation is signalled by an abrupt increase in montmorillonite content regardless of the previous assemblage. This change in mineralogy cannot be ascribed directly to an intensification of bottom current activity, as has been proposed for the unconformity. The same increase in montmorillonite deposition is also present on the Rio Grande Rise and, to a lesser extent, on the São Paulo Plateau, areas that are topographically isolated from the effects of deep bottom currents. A climatic explanation is also not feasible for this change in clay mineral content because of its occurence in both equatorial and high latitude locations.

The widespread and time correlative introduction of a montmorillonite clay to both basinal and ridge sites and its association with clinoptilolite and with volcanic breccia on both the Rio Grand Rise and Walvis Ridge strongly suggest that the South Atlantic in early Tertiary time, and especially in the Eocene, was dominated by volcanic activity.

Highest concentration of montmorillonite clays seems centered in the Rio Grande-Walvis Ridge system, with the basins showing a somewhat less intensive change. This distribution suggests that the east-west ridge system was the source of much of the volcanogenic sediment. Volcanic activity in the Rio GrandeWalvis Ridge region, however, is seemingly too distant to have greatly influenced the sediment of the Ceará Rise. The presence of a similar montmorillonite clay there suggests additional and simultaneous centers of volcanic activity in the more equatorial regions of the South Atlantic. Gibson and Towe (1971) note other extensive areas of volcanically derived sediment in the Caribbean and suggest that widespread Eocene chert deposits and an increase in biosiliceous productivity result from the process of ash alteration. Early Tertiary volcanism, therefore, appears to have been common throughout the Atlantic.

\section{Sediment Dispersal}

The climatic deterioration and growth of an Antarctic ice sheet during early Tertiary time apparently has not greatly influenced the complexion of the South Atlantic clay mineralogy. The initiation of Antarctic glaciation and the intensification of thermohaline circulation may be the immediate agent for the widespread erosional episode producing the CretaceousTertiary unconformity. However, the most obvious clay mineral variations do not appear to be related to bottom current distribution, but rather seem to be associated primarily with volcanic episodes. Although no direct evidence of transport mode can be ascertained from the stratigraphic column, dispersal of ash through the atmosphere initially and then redistribution during settling through the water column are the most probably transport paths for volcanogenic fine sediment.

Large amounts of well-crystallized illite, expected from an Antarctic source, are not being transported into the South Atlantic by AABW. The high rate of sedimentation in the Argentine Basin (Site Report Chapter 358) may, at least in part, be ascribed to the influx of biosiliceous material by AABW, but no evidence exists for significant long-distance transport of terrigenous material from polar regions. Illite dilution of the early Tertiary montmorillonite facies is most likely an effect of the more direct sediment input into the Argentine Basin from the South American continent. Studies of the lithofacies distribution (McCoy and Zimmerman, this volume), however, indicate a southward transport of fine sediment through Hunter Channel commencing in early-mid Tertiary time. It is possible that some of the illite dilution may be a reflection of this influx, but the extent of this input has, as yet, not been determined.

The clay mineral stratigraphy of the Brazil Basin shows no similar dilution trend. It is unlikely, therefore, that northward transport of fine material through the Vema (or Hunter) Channel has occurred in amounts significant enough to alter the indigenous clay mineralogy. Furthermore, deposition of clay as a dissolution facies has occurred in the Brazil Basin in time periods before the initiation of AABW circulation (McCoy and Zimmerman, this volume). In the early Tertiary, the Brazil Basin is dominated by the montmorillonite-volcanic facies alternating with a variable illite content. The character of the two clay facies is similar to that of the São Paulo Plateau, suggesting both an oceanic influence and an intermittent illite input from the South American continent. Distal turbidity current deposition (Site Report Chapter 355), for the terrigenous illitic input, is the most likely form of dispersal into the deeper reaches of the Brazil Basin.

Clay mineral stratigraphy also records a significant dispersal event in the sediment column of the Ceará Rise. This is the initiation of Amazon River drainage and the deposition of the Amazon Cone in mid to late Miocene time, which agrees with other estimates (e.g., Damuth and Kumar, 1975). The character of the modern inner-shelf fine sediments near the Amazon River (Barreto et al., 1975) is similar to the late Miocene to Recent clays of the Ceará Rise (some clays from the outer shelf have a high montmorillonite content and apparently are relict and not derived from the 
modern Amazon). The increase of the terrestrial component (illite and chlorite) on the Ceará Rise at the expense of montmorillonite, probably occurs by distal turbidite deposition since only the fine fraction of the sediment is involved (Site Report Chapter 354).

\section{CONCLUSIONS}

Results of this study clearly reflect the effects of tectonic and paleooceanographic evens upon the clay mineral stratigraphy.

1) The clays of the South Atlantic Ocean are dominated by two mineralogical facies: an "oceanic" assemblage consisting of montmorillonite and associated zeolite with a volcanic origin and, a "continental" assemblage consisting dominantly of illite with variable amounts of kaolinite and chlorite.

2) Diagenetic alteration of the continental clay assemblage appears to be minimal in DSDP cores. Alteration of the volcanic suite, however, is recognized as a common phenomenon.

3) Introduction of well-crystallized illite from the Antarctic continent by AABW is not a significant factor for deposition in the Argentine Basin.

4) No clear evidence exists for large-scale bottomcurrent transport of fine sediment between the basins of the southwestern Atlantic. Transport southward, however, from the Brazil to the Argentine basins via Hunter Channel may have taken place.

5) An abrupt increase in montmorillonite content occurs in both basin and ridge sites during the Eocene. The broad distribution of this material suggests that the entire South Atlantic was subjected to a period of extensive volcanic activity at this time.

\section{ACKNOWLEDGMENTS}

The author wishes to thank the Deep Sea Drilling Project for the opportunity to participate on Leg 39 and his fellow shipboard scientists and staff for their collaboration and unflagging good humor. Drs. Floyd McCoy, Jorn Thiede, and Peter Supko read the manuscript and offered constructive comments. I am grateful to the staff of the Core Laboratory at the Lamont-Doherty Geological Observatory for their aid in sampling the piston cores for this investigation. The Core Laboratory is supported through funds of the Office of Naval Research, N-0014-67-A-0108-0004, and the National Science Foundation, GA-35454. I also wish to thank Union College for making available the facilities of the Cooledge X-ray Laboratory.

\section{REFERENCES}

Barreto, L.A., Milliman, J.D., Amaral, C.A.B., and Francisconi, O., 1975. Upper continental margin sedimentation off Brazil, Part II-Northern Brazil: Contrib. Sedimentol., v. 4 , p. 11-43.

Biscaye, P.E., 1964. Distinction between kaolinite and chlorite in recent sediments by X-ray diffraction: Am. Mineralogist, v. 49, p. 1281-1289.

1965. Mineralogy and sedimentation of Recent deep-sea clay in the Atlantic Ocean and adjacent seas and oceans: Geol. Soc. Am. Bull., v. 76, p. 803-831.

Chamley, H., 1967. Possibilités d'utilisation de al cristallinité d'un minéral argileux (illite) comme té moin climatique dand les sédiments récents: C.R., Acad. Sci., v. 265, p. 184-187.
1972. Signification paléoclimatique des sédiments argileux quaternaires de Méditerranée occidentale: Extrait du Mémoire du B.R.G.M., no. 77.

Chester, R., Elderfield, H., Griffin, J.J., Johnson, L.R., and Padgham, R.C., 1972. Eolian dust along the eastern margins of the Atlantic Ocean: Mar. Geol., V. 13, p. 91105.

Damuth, J.E. and Kumar, N., 1975. Amazon Cone: Morphology sediments, age, and growth pattern: Geol. Soc. Am. Bull., v. 86, p. 863-878.

Da Rocha, J., Milliman, J.D., Santana, C.I., and Vicalvi, M.A., 1975. Upper continental margine sedimentation of Brazil, Part V-Southern Brazil: Contrib. Sedimentol., v. 4 , p. $117-150$.

Eittreim, S., Thorndike, E.M., and Sullivan, L. in preparation. Turbidity distribution in the Atlantic Ocean.

Gibbs, R.J., 1968. Clay mineral mounting techniques for Xray diffraction analysis: a discussion: J. Sediment. Petrol., v. 38 , p. $242-244$.

Gibson, T.G. and Towe, K.M., 1971. Eocene volcanism and the origin of Horizon A: Science, v. 172, p. 152-153.

Goldberg, E.D. and Griffin, J.J., 1964. Sedimentation rates and mineralogy in the South Atlantic: J. Geophys. Research, v. 69 , p. 4293-4309.

1970. The sediments of the northern Indian Ocean: Deep-Sea Res., v. 17, p. 513-537.

Griffin, J.J., Windom, H., and Goldberg, E.D., 1968. The distribution of clay minerals in the world ocean: Deep-Sea Res., v. 15, p. 433-459.

Hashimoto, I. and Jackson, M.L., 1960. Rapid dissolution of allophane and kaolinite-halloysite after dehydration: In Swineford, A. (Ed.), Clays and clay minerals, v. 7: London (Pergamon Press).

Heath, G.R., 1969. Mineralogy of Cenozoic deep-sea sediments from the Equatorial Pacific Ocean: Geol. Soc. Am. Bull., v. 80, p. 1997-2018.

Jackson, M.L., 1969. Soil chemcial analysis-advanced course: 2 nd Ed., Pub. by the author, Dept. of Soil Science, Madison (Univ. of Wisconsin).

Jacobs, M.B., 1974. Clay mineral changes in Antaractic deepsea sediments and Cenozoic climatic events: Jr. Sediment. Petrol., v. 44, p. 1079-1086.

Jacobs, M.B. and Hays, J..D., 1972. Paleo-climatic events indicated by mineralogical changes in deep-sea sediments: J. Sediment. Petrol., v. 42, p. 889-898.

Kolla, V. and Biscaye, P., 1975. Climatology and mineralogy of the Indian Ocean sediments: Geol. Soc. Am., Abstracts with Programs, v. 7, p. 1150.

Peterson, M.N.A. and Griffin, J.J., 1964. Volcanism and clay minerals in the southeastern Pacific: Jr. Mar. Res., v. 22, p. 13-21.

Rateev, M.A., Gorbunova, Z.N., Lisitzyn, A.P., and Nosov, G.L., 1969. The distribution of clay minerals in the oceans: Sedimentology, v. 13, p. 21-43.

Rex, R.W., 1969. X-ray mineralogy studies-Leg 1. In Ewing, M., Worzel, J.L., et al. Initial Reports of the Deep Sea Drilling Project, Volume 1. Washington (U.S. Government Printing Office), p. 354.

Windom, H.L., 1969. Atmospheric dust records in permanent snowfields: implications to marine sedimentation: Geol. Soc. Am. Bull., v. 80, p. 761.

Yeroshchev-Shak, V.A., 1961a. Illinite in the sediments of the Atlantic Ocean: Doklady Akad. Nauk S.S.S.R., v. 137, p. 951-953.

1961b. Kaolinite in the sediments of the Atlantic Ocean: Doklady Akad. Nauk S.S.S.R., v. 137, p. 695697. 
1962. The clay minerals in Atlantic Ocean sediments: Okeanologiia; Akad. Nauk S.S.S.R., v. 2, p. 98105.

Zemmels, I. and Cook, H.E., 1973. X-ray mineralogy of sediments from the central Pacific Ocean. In Winterer, E.L., Ewing, J.I., et al., Initial Reports of the Deep Sea Drilling Project, Volume 17: Washington (U.S. Government Printing Office), p. 517.
Zimmerman, H..B., 1972. Sediments of the New England continental rise: Geol. Soc. Am. Bull., v. 83, p. 37093724.

1975. Patterns of fine sediment dispersal, North Atlantic Ocean: Extraits des publications du congrés, Ninth International Congress of Sedimentology, Nice, France, p. 77-79. 